Informasi - ISSN (p) 0126-065o; ISSN (e) 2502-3837

Vol. 5o, No. 1 (2020), pp. 85-96, doi: http://doi.org/10.21831/informasi.v50i1. 30169

\title{
The social harmony of local religious groups
}

\author{
Hapsari Dwiningtyas Sulistyani \\ Department Communication, Faculty of Social and Political Science, \\ Universitas Diponegoro, Indonesia \\ Hapsarisulistyani@yahoo.com \\ Turnomo Rahardjo \\ Department Communication, Faculty of Social and Political Science, \\ Universitas Diponegoro, Indonesia \\ turnomorahardjo@gmail.com

\section{Lintang Ratri Rahmiaji} \\ Department Communication, Faculty of Social and Political Science, \\ Universitas Diponegoro, Indonesia \\ lintangratri84@gmail.com
}

Article History: Received 2020-02-12, Revised 2020-07-24, Published 2020-07-30

\begin{abstract}
As a multicultural nation, minority groups are embedded in the discourse of nationality and social harmony in Indonesia. The term social harmony signifies that each race, ethnicity, or religion must be placed in an equal standing/position. The research focuses on understanding the identity negotiation strategies, in establishing the social harmony, that are used by adherents of local religions which are considered minorities in a community where the majority of people believe in formal religions. This study uses the Co-Cultural Theory and employs a phenomenology research method to explores the way in which co-cultural groups' members negotiate their cultural differences with the members of dominant groups. The groups that are chosen as the subject of this research are the religious groups that live in a relatively supportive community (Kawruh Jiwa) and the group that has experienced numerous clashes with other groups in the region (Sapta Dharma). The result of the research indicates that communication strategies used by local religious believer groups in establishing social harmony are: educating others, self-censoring, and bargaining. Those three communication strategies create different co-cultural positions. Educating others creates an accommodation position, self-censoring produces surface assimilation, and bargaining strategy generates a situation where marginal groups are in a partial separation.

Sebagai negara multikultural, kelompok minoritas berada dalam wacana kebangsaan dan keharmonisan sosial di Indonesia. Istilah harmoni sosial menandakan bahwa setiap
\end{abstract}


ras, etnis, atau agama harus ditempatkan dalam posisi/kedudukan yang sama. Penelitian berfokus pada pemahaman strategi negosiasi identitas, dalam membangun sosial harmoni, yang digunakan oleh penganut agama lokal yang dianggap minoritas dalam sebuah komunitas di mana mayoritas orang percaya pada agama formal. Penelitian ini menggunakan teori co-cultural dan menggunakan metode penelitian fenomenologi untuk mengeksplorasi cara anggota kelompok budaya yang berbeda menegosiasikan perbedaan budaya mereka dengan anggota kelompok dominan. Kelompok-kelompok yang dipilih sebagai subjek penelitian ini adalah kelompok agama yang hidup dalam komunitas yang relatif mendukung (Kawruh Jiwa) dan kelompok yang telah mengalami banyak bentrokan dengan kelompok lain di wilayah tersebut (Sapta Dharma). Hasil penelitian menunjukkan bahwa strategi komunikasi yang digunakan oleh kelompok penganut agama setempat dalam membangun kerukunan sosial adalah: mendidik yang lain, menyensor diri sendiri, dan tawar menawar. Ketiga strategi komunikasi itu tercipta posisi co-cultural yang berbeda. Mendidik orang lain menciptakan posisi akomodasi, swasensor menghasilkan asimilasi permukaan, dan strategi perundingan menghasilkan situasi di mana kelompok marginal berada dalam pemisahan parsial.

Keywords: Identity Negotiation, Social Harmony, Marginal Group, Local Religions, Co-Cultural Theory

\section{INTRODUCTION}

This research focuses on understanding the identity negotiation strategies that are used by believers of local religion which are considered minorities in a community where the majority of people believe in formal religions. This study uses the CoCultural Theory as a reference for describing how groups of people who believe in local religion communicate in a structure that considers them as a minority. This research attempts to describe the specific practices of communication that are used by the believers of local religion when performing an identity negotiation with the dominant group as an attempt to establish social harmony.

Kung et.al (Kung et al., 2018) argue the intergroup social harmony is primarily constructed by the trust. The perception of an intergroup boundary often blocks the extension of trust to different cultural/ religious groups. According to the National Commission of Human Rights (Komnasham, 2016), marginal groups in Indonesia is categorized into five clusters, which are marginalization based on race, ethnicity, religion and belief, disability, and sexual orientation (Komnasham, 2016). One of the minority groups that has a long history of marginalization are groups of local religion believers. They are subjected to discrimination invarious aspects of theirlives, such as issues regarding birth, education, marriage, and even death. In other words, they are marginalized from the moment they are born until they pass away. They must endure lifelong discrimination regarding the identity of the local religion group they are in. Ironically, history has also shown that the government has established laws that enforce acts of discrimination towards the adherents of local religions. For example, the Ministry of Religion in 1959 defines religion as a group that exists based on revelations from God and has prophets, holy book, guidance as well as a law system that its believers can follow (Mellisa, 2015). That kind of definition insinuates that local religion is not considered as a "religion" and it is determined to be a deviation in society. Another law that corners local religion believers and is still used until now is the "Undang-undang nomor 1/PNPS tahun 1965" regarding the misuse and/or the blasphemy of religion. According to the National Commission of Human Rights (Erdianto, 2017), the law previously stated is discriminative and limits the freedom of praying for the believers in local religion and beliefs. That law is then reinforced with the provision of the People's Consultative Assembly (MPR) stating that local beliefs are not a religion and the believers will not 
Hapsari Dwiningtyas Sulistyani, Turnomo Rahardjo, \& Lintang Ratri Rahmiaji, The Social Harmony ...

be guaranteed the full rights regarding performing and practicing their religion. Besides the laws stated before, there are still many rules, consensus, and policies that have the potential to create marginalization towards the believers of local religions.

Rules regarding beliefs and religion of minorities have reinforced the stigma and acts of marginalization in society. The restriction of freedom to pray and having a particular religious belief usually triggers acts of violence. One of the examples is the refusal of the villagers regarding the funeral location when one of the believers of Sapta Dharma in Brebes passed away. It was planned that the person will be buried in the village's public graveyard. The refusal of the villagers caused a 12-hour delay in the funeral process and was finally buried in the backyard of the person's home (Priyanto, 2017). Other acts of violence that befell the believers of Sapta Dharma was the burning of the Sapta Dharma Sanctuary on the 1oth of November 2015 in the Rembang District, Central Java. Before the sanctuary was burned, the followers of Sapta Dharma had received intimidation and threats regarding them performing an ongoing renovation towards the sanctuary. The district's government was unable to provide protection and even asked them to stop the renovation. Cases of violence that are endured by followers of local religions indicate the lack of protection towards the Freedom of Having Religion and Faith.

This paper is an attempt to create a co-cultural communication model that is performed by the adherents of local religions. This paper focuses on two groups of local religions which are: the Kawruh Jiwa in Salatiga and the Sapta Dharma in Brebes. The Kawruh Jiwa believers in Salatiga can relatively co-exist with the majority of religious communities. Meanwhile, the Sapta Dharma believers in Brebes has encountered issues with the other residents like the refusal of burying a Sapta Dharma believer in the public graveyard. This paper hopefully can reveal the communication strategy that is used by the local religion believers as a form of their identity negotiation.
The research regarding identity negotiation of local religion believers has several references from previous researches. The first research is title a study related to mindfulness in interethnic communication that explored the communication between people of Chinese ethnicity and Javanese ethnicity in Sudiroprajan, Surakarta (Rahardjo, 2004). The aforementioned research focuses on the recurring conflicts in Indonesia is then made as an indication that mindless situations are still happening during inter-ethnic communications. Every individual frombothgroupstend tobereactive rather than proactive, and interpreting behaviors of individuals from the other group based on their own group's perspective. The result of Rahardjo's research shows that citizens of both ethnicities in that region can create mindful communication situations because they have sufficient competency in intercultural communication which consists of integrating motivation, knowledge, and skills to be able to communicate properly and efficiently. Rahardjo's research regarding mindfulness in interethnic communication is important to be made as a foundation in seeing the forming process of mindfulness when co-cultural groups communicate with dominant groups that will finally create social harmony.

The second research is a research that focused on building a communication model in a multireligion Society (Rahardjo \& Lukmantoro, 2015). The goal of that research is to discover society's view on religion-based conflicts. The communication gap between different individuals is then brought up in Rahardjo and Lukmantoro's research and it is discovered that each individual can create good relations without minding each other social, economic, and religious backgrounds. Each side that commences interaction has high-involved people that are indicated with the showing of respect towards other people. In performing interactions, they tend to be open towards understanding the other side that has a different religion. In social relations, they not only show involvement in socializing but also willing to respect 
other people's religious values and customs (Rahardjo \& Lukmantoro, 2015). Another finding in this study is reinforcing that dialog is the most suitable communication model that needs to be implemented in a multireligion society. This research by is important for this research because it can be made as a foundation for seeing the communication model that arises in a society with different religions and beliefs.

The last research used is by Glenn and Johnson that uses Co-Cultural Theory to explore how African-American college students engage and implement communication strategies when socializing in a predominantly caucasian college (Glenn \& Johnson, 2012). Three important points have been found in the research: (a) aggressive assimilation: in negotiating stereotypes and personal-identity, (b) Non-assertive detachment: in negotiating subordination and imbalance of power, and (c) pursuit for accommodation: solved by performing communication strategies. Research showed the theoretical implications of the Cocultural Theory (Glenn \& Johnson, 2012). Tension arises when there is an identity conflict between personal identity and the identity performed by the dominant group. The implications of the identity conflict is an identity gap between participants that leads them to perform identity strategies such as aggressive assimilation and nonassertive detachment. This research is useful for showing how communication strategy from marginal groups that live in a dominant community.

This paper explores the understanding of how the co-cultural group members negotiate the cultural differences with other groups. The group that is chosen to be the subject of this paper is the group that in a relatively supportive community towards the existence of local religion believers (the Kawruh Jiwa group in Salatiga) and a group that has experienced numerous clashes with other groups in the region (Sapta Dharma group in Brebes). The understanding of cocultural communication strategies from local religion believers group will be the foundation in constructing a co-cultural communication strategy model.

\section{LITERATURE REVIEW}

The presence of minority groups is a consequence of a multi-cultured country. Jubbaet.al (2019) argue that in Indonesia there are many inequalities regarding protection and equity of rights between minority groups and the majority. This injustice is particularly evident in the treatment of the dominant groups, including the government, towards minority religious groups (Jubba et al., 2019). Ideally, the country should protect the rights and safety of every minority groups including minority groups concerning religion and beliefs. But in reality, the groups of local believers in Indonesia have a long history of marginalization. They experience identity discrimination in various important phases of their lives such as birth, education, marriage, and even death.

The presence of local religious groups is found in almost all regions in Indonesia. Ironically, the offense towards Freedom of Having Religion and Faith is also found in almostall regionsin Indonesia (Hafiz \& Dja'far, 2016). The position and social construct of local religious groups are very vulnerable to discrimination that can be seen from the number of offenses that has gone up since 2014. In other words, the freedom of having religion and belief for local religion minority groups has not been fully guaranteed. Levin et.al argue that there is always debate about the laws that govern and protect religious freedom (Levin et al., 2016) . In Indonesia, the inconsistency of laws governing religion is caused by the tug-of-war between the discourse of religious freedom and people's fear of particular religion branches, especially local religions, that are considered as the deviation of the dominant formal religions. Local religion believer groups as a minority perform a co-cultural communication as an effort to be able to co-exist with the majority religious groups.

The study of cultural diversity has a very broad scope in terms of theoretical and models because it incorporates various 
problems of diversity, multiculturalism issues, intercultural conflicts, and inequalities that take place throughout the world (Sloan \& Schmitz, 2018). The cultural communication perspective that is applied to this social harmony in local religious groups research is critical multiculturalism. Critical multiculturalism is a study of cultural communication that not only describes the cultural diversity in society but also unravels the complex injustices and power relations processes that exist in a multicultural society (Sloan \& Schmitz, 2018). Research that utilizes a critical multiculturalism approach problematizes the injustices that occur in the social structure and attempt to challenge the inequalities by listening and explaining the particular perspectives of marginal groups (Sloan \& Schmitz, 2018). Understanding the social structure and public institutions that govern power relations in a multicultural society needs to be done to be able to understand the various obstacles that prevent theparticipation of minoritygroupsincluding religious minorities in social, economic, and political arenas (Tremblay, 2019). Therefore, the multiculturalism perspective applied to this research is multiculturalism in an active sense. Active multiculturalism argues that the nature of multiculturalism is closely related to the dynamic nature of power relations in the communication process that occurs within society (Spiteri, 2017). By using an active multicultural perspective, this research focuses on efforts to reveal the injustices experienced by minority groups and encourage social justice in a multicultural society. Each race, ethnicity, or religion even though they are different can be placed in an equal standing/position (Lubis, 2015). It can also possess similarities in rights regarding articulating and expressing their views and values.

According toGuptaet.al.(2018), suspicion and bias towards other groups occur in both dominant groups and marginal groups. Therefore, co-cultural communication activities need not only be seen from the perspective of marginal groups but also need to be assessed from the perspective of the dominant group (Gupta et al., 2018). Rasna \& Tantra argue that religion has an important role in molding the character of its followers (Rasna \& Tantra, 2017) . Religion has an important role in developing mindful attitudes and behaviors in a particular society. The principle of respecting other religions and the commitment to teach peace that exists in the principle of almost all religions is significant to be used as a basis for developing acceptance to different religious groups (Shaver et al., 2016). The mindfulness co-cultural competence is the basis for the formation of social harmony in a society.

Co-cultural Theory is developed by Mark Orbe, which is a theoretical thinking regarding conversations between individuals from underrepresented groups and dominant groups (Littlejohn et al., 2017). Orbe refers to underrepresented groups as co-cultural groups, which are groups having a lower social status like homeless people, deaf people, or in an American context are African-Americans. Meanwhile, the dominant groups come from the main flow of society and often but not always, are the majority groups in a culture. They usually are people who have a higher social status and power in society, for example, people with high socio-economic status.

According to Orbe and friends, cocultural communication relates to the interaction between the underrepresented group members with dominant groups. The focus in Co-cultural Theory is providing a structure where co-cultural group members. Co-cultural Theory has two propositions, which are 1) The marginalized co-cultural group members in a dominant social structure and 2) The co-cultural group participants that practicing certain communication strategies to obtain success when encountering authoritative powerful structures. Orbe and friends mentioned co-cultural communication approaches specifically which are: avoiding, imitating, adopting, stereotypes, and self-censoring towards teaching others, transaction, tackling, and sabotaging others.

Commonly, co-cultural members have 
one out of the three goals; assimilation, accomodation, or separation, when they are interacting with the members of thedominant group (Littlejohn et al., 2017). Assimilation is a situation where someone who is part of an underrepresented group attempts to become part of a dominant cultural group. Whereas accommodation is a state in which a marginal person tries to accept the dominant culture while maintaining a part of the uniqueness of the original culture. The circumstance of accommodation, in other words, is an effort of minority group members to be accepted by the dominant cultural group. Separation, on the other hand, is a position where minority group members reject the dominant culture altogether and try to maintain their particular culture and form a social structure that sustains the unique cultural values (Littlejohn et al., 2017)

In the context of the application of CoCultural Theory, the use of Co-Cultural Theory in various researches involve the following premises: the existence of social hierarchy, the dominant group uses its power to strengthen the power system, dominant power structures restrain the participation of minority groups, how the minority groups communicate signify the way power relations operate in a particular society, and minority groups use specific communication strategies for maintaining their social existences (Razzante \& Orbe, 2018). Contextualization of Co-cultural Theory in this study is carried out by analyzing how communication strategies applied by local religious groups to be able to create social harmony with adherents of formal religion who are the dominant group. The position of local religious groups as marginal has forced them to implement particular communication strategies as a mode of survival.

\section{METHODS}

The Identity Negotiation Strategies of Local Minority Religious Groups (The Contextualization of Co-Cultural Theory) is an analysis that uses a descriptive qualitative approach. In term of operational aspects, this study describes identity negotiation strategies of the research subject which are local religion believers and the obstacles in communication that arises when they are interacting with the majority religious group. Tools or method that is used in this research is phenomenology through qualitative interview and observation to obtain data regarding co-cultural communication between local religion believers with the dominant society. The subject of this research is the Kawruh Jiwa religion group in Salatiga and the Sapta Dharma religion group in Brebes that performs communication with people from dominant religious groups.

Qualitative researchers interpret data by giving meaning, translating, and making the data understandable by finding out how the subject of the research views the world and how they define situations (Neuman, 2007). Because this research employs a phenomenological research method, the notion of meaning perceives as a relational term rather than isolated, and active or dynamic processes rather than passive or motionless entities (Harney, 2015). This research is descriptive qualitative research. According to Cibangu \& Hepworth (Cibangu \& Hepworth, 2016), as descriptive research, phenomenology explores a particular phenomenon in detail and in-depth. Therefore this research use observation and in-depth interview as the data collection methods.

The study begun by observing the cultural environment in which local religious followers interact with their neighbors in everydaylives. The researchersalsoconducted interviews with the followers of Kawruh Jiwa and Sapta Dharma. The data gathered were then made in the form of transcripts which are then rearranged in the form of pattern analysis. The main attempt of the pattern analysis is revealing the configuration of meaning, whether it is the structure or how the meaning of identity negotiation itself was created. In the context of this research, the pattern analysis was done for uncovering similarities and uniqueness of experience that is possessed by local religion believers when applying communication strategies 
with the dominant groups.

The researcher made a descriptive narration based on the interview dialog with the informants. The descriptions mainly explained the experiences of informants in establishing interactions with adherents of the majority religion. The description was done by reading and observing in detail to identify the similarities and uniqueness in the communication pattern as a means to develop an identity negotiation adaptation strategy communication model. After the description of informants' experiences was carried out, the next step in this research was to synthesize the textural and structural meaning, which was to conduct an analysis or discussion of the research findings (experience of communication of local religious followers) by referring to the theories of identity negotiation that relevant with research results. The final step in this phenomenological research was to discuss the implications of the research results culturally and socially.

\section{RESULTS AND DISCUSSION}

This research focuses on two local religious community groups namely Kawruh Jiwa and Sapta Dharma. The results showed that the two minority This research focuses on two local religious community groups: Kawruh Jiwa and Sapta Dharma. The results of the research showed that the two minority groups implemented different strategies when communicating with the surrounding community.

Kawruh Jiwa is a local religious group that has a different political and social position from formal religions. The position as a minority religion makes Kawruh Jiwa have several specific ways of communicating when interacting with dominant groups. Kawruh Jiwa spread their religious thoughts through routine and nonroutine discussions. Some of the followers of Kawruh Jiwa received information about the principles of their religious perspective when attending discussions in scientific forums. Some other Kawruh Jiwa followers get information from people who have already become followers. According to Eyber et.al (Eyber et al., 2018), religious leaders have a significant role in the success of co-cultural communication of religious groups. The cocultural communication activities carried out by the Kawruh Jiwa group are strongly influenced by the ability of the Kawruh Jiwa's leader in moderating the way in spreading the religious principles of Kawruh Jiwa to the society at large. The leader of the Kawruh Jiwa group uses a communication strategy that promotes togetherness and tolerance. According to Asmara (Asmara, 2018), most religious groups have universal values of kindness such as love, brotherhood, and a prohibition against attacking and hostility towards other people or groups. If every religious group applies the principles of goodness that they have thoroughly, it will form social harmony in society. The rhetorical and social competences of the leader have led the acceptance of Kawruh Jiwa religious group in the surrounding community. Regular discussion forums are held every month called jonggringan. The forum strengthens understanding for followers and also provides information for potential followers. Often adherents bring their friends to join jonggringan.

Whereas Sapta Dharma, on the other hand, identifiesSaptaDharmaasareligionthat has the same position as formally recognized religions. The way of communication that focuses on spreading their beliefs makes them suspected of being a deviant religion by the surrounding community so that it often generates conflicts. Such suspicion also makes them discriminated against. They are often forced to explain their rituals and beliefs to the surrounding community. When adherents of Sapta Dharma try to become part of a community, they are often persuaded and asked to convert to become adherents of one of the government formally recognized religions. When followers of Sapta Dharma refuse to join the dominant religion, they experience discrimination in the form of insults, excluded from social events, and even there were some cases when members of Sapta Dharma died their bodies 
were rejected by the community to be buried in public graves. Some even buried their relatives who died in the front yard of the house.

The religious mindset is based on the values of goodness which are relatively similar in almost all religions (Kriještorac, 2018). Thus, these values are flexible enough to be able to bring up new interpretations that suitable or support the specific social conditions at a time. Thus, the basic perspective on religion should be changed, because the values of goodness are relatively the same in all religions so that religion should be seen as a social unifier, not as a source of division (Kriještorac, 2018).

chuah et. al. (Chuah et al., 2016) argue that religiosity relates to prejudice and trustworthiness. In a religious society, people tend to perceive that people who belong to some faith are more trustworthy. In Indonesia, people who affiliate in local religions are more likely to get discrimination due to general stereotypes and prejudices. According to Gudykunst (Gudykunst, 2002) and, co-cultural communication that is done by marginalgroups havethreemain purposes/ goals which are: assimilation (being a part of the dominant group), accommodation (trying to convince the dominant group to accept the presence of marginal groups), and separation (separating from the dominant group). However, this research shows that the three purposes mentioned above cannot be accomplished in the same way as mentioned in Co-cultural Theory. Based on the results, there are variants of assimilation, accommodation, and separation that are specific to the local religion believers identity negotiation.

The first strategy is accommodation implemented by explaining their religious beliefs through humor. This strategy is mainly used by supporters of Kawruh Jiwa. This strategy is mainly used by those who have great rhetorical abilities. They try to explain their belief in the dominant society. They explained that their belief was not the same as formal religions. Kawruh Jiwa focuses more on the philosophy of life to create comfort for themselves and the people around them. Negotiation strategies also involve humor. They try to show the logical and human sides of their faith. They use logical empirical methods to explain their beliefs. The logic gives the impression as harmlessly "funny" when seen by the dominant religions' believers that do not use empirical thinking to explain their dogmas. Surrounding communities can accept them because they perceive the Kawruh Jiwa's way of thinking as not a threat to their religious life. The accommodation that can be accomplished by some believers of a local religion is done through an explanation using mindset irony humor. Adept rhetorical ability is highly required in order to achieve accommodation with a humorous explanation strategy. The locals that are already used with the difference and have known communicators play an important part in the acceptance of marginal groups. Open discussions and the courage to explain the beliefs and rules are key to succeed in performing humor explanation strategy.

The second strategy is surface assimilation which is pretending to be part of a dominant religion (self-censoring). Some believers of Kawruh Jiwa use this strategy by stating that their religion is Islam (Moslem) on their identity cards. The surrounding community still views them as Muslims even though they believe in Kawruh Jiwa. This surface assimilation strategy makes the dominant community accept them because they are legally declared Muslim. They are also still involved in religious activities held by the local community. The local religion adherents who use surface assimilation strategies by convincing the surrounding community that they embrace formal religion even though secretly they practice the Kawruh Jiwa's rituals. Assimilation that appears from this research is surface assimilation. Surface assimilation is a strategy performed to blend in with the dominant religious group. They do not really adopt the dominant religion but only using its identity in order to be accepted in society. The findings in this research show how assimilation can bea part of the minority 
group's strategy to not look significantly different from the dominant.

Meanwhile, the separation that is done by the adherents of a local religious group tends to be partial. The cultural negotiation position they agreed on was a partial separation because they still try to participate in dominant religious activities in their community such as Slametan. According to Boogert (Boogert, 2017), Slametan ritual is a cultural gathering that is currently a representation of syncretism in Javanese society. Slametan ritual is a combination of Javanese beliefs in theera before the dominant religions (local religions) and formal religions that exist today (predominantly Islam). The co-cultural strategy of the marginal religious group (Sapta Dharma) is to participate in the Slametan ritual even though the prayers practiced in the Slametan are Islamic prayers. But unfortunately, some communities did not invite or even reject the presence of Sapta Dharma followers at the Slametan event. Communication strategies carried out openly reveal the identity they believe to be a different religion from formal religion. They also do not hide their ritual practices. In other words, they are relatively open to practicing a different religion from the formal religions. Religious marginal groups appear to not fully show a completely different or separate identity with the dominant groups. The members of local religious groups that are courageous to show their own identity even though only partially have to face discrimination and violence from the dominant religious groups.

Thus, barriers to establishing social harmony for local religious groups are triggered by out-group prejudices and stereotypes. Therefore, in terms of social harmony, the marginal religious group must be adapting their strategies and goal so that they can be accepted in society. The marginal local religious group should embrace the surrounding dominant culture's structure of rules, utterances, and the codes of speech (Chornet \& Parr, 2017). The appropriation of the dominant culture system is used as a negotiation identity strategy so that the local religious groups can be accepted by the dominant while still maintaining their distinct cultural identities (Simmons, 2013). The interaction of identity negotiations between minoritygroupsand minoritygroups in this study is in line with the arguments of Turner-Zwinkels, Postmes, and van Zomeren (Turner-Zwinkels et al., 2015) regarding how group philosophy will contribute to the actions and attitudes of individual members when interacting with outsiders. The Kawruh Jiwa Group places more emphasis on the acceptance of the surrounding community so that they communicate their principles with discussion and humor. Kawruh Jiwa does not place their group as a specific religion but prefers to create an open discussion forum on their philosophical thoughts which are carried out with ease and humor. The principles of Kawruh Jiwa's philosophy make their members communicate their beliefs in a way that promotes harmony with the surrounding community. Sapta Dharma, on the other hand, has a philosophy to place their religious beliefs and rituals as things that must be displayed openly. This philosophy allows individuals who are members of Sapta Dharma to openly show their religious identity. Different co-cultural negotiation strategies produce different degrees of acceptance of the surrounding community towards the two local religious groups that have become the subject of this study.

In other words, diversity in a society leads to social dynamics that can create social harmony or conflict or division. Jong \& Twikromo argue that there is always friction in a diverse society and, depending on time, area, and space, this will be harmonized, restored, generated, or even exploded into a prolonged conflict (Jong \& Tiwikromo, 2017) . Sociocultural harmony is dynamic that can be modified, or adjusted, depending on social context and political interests. Differences and similarities in a community can sometimes be a threat but sometimes it is also beneficial if mutual understanding between different groups emerged (Jong \& Tiwikromo, 2017). Kawruh Jiwa is a local religious group whose existence can lead to a 
beneficial religious dynamic that encourages tolerance and understanding toward cultural diversity. In the Kawruh Jiwa religious group social harmony can emerge because members of the Kawruh Jiwa manage to communicate and create a social position that can be accepted by the dominant society. The state of social harmony develops because the Kawruh Jiwa group initiates discussions through dialogue forums that open to the public and involve the surrounding community.

Whereas the existence of Sapta Dharma in the community, on the other hand, tends to bring disharmony because of the separation acts shown by the adherents. They tend to be closed and separate from the surrounding community. Sapta Dharma religious group had an unfavorable social position because the dominant society viewed the group as a deviant cult that could damage the social order.The separation attitude, however, to some extends is a defense mechanism due to the surrounding community rejection of the Sapta Dharma religious practices. Therefore, social harmony can be created in a multicultural society if all parties involved seek to create an open sphere for dialogues because the dialogue is not only able to assist equality but more importantly it encourages the emergence of various voices.

\section{CONCLUSION}

Religion-based minority groups have to perform identity negotiation through cocultural communication to be accepted by dominant groups. Compared to the previous research in the co-cultural areas, the novelty of the results of this study lies in specific adaptation strategies that emerged from the particular social position of local religions adherents in society. The various strategies implemented by the local religious adherents to communicate with people outside their groups are educating others, self-censoring, and bargaining. Those three communication strategies signify different co-cultural positions. Educating others creates an accommodation position, self-censoring produces surface assimilation, and bargaining strategy generates a situation where marginal groups are in a partial separation. The result also implies that there is an apparent improvement in terms of co-cultural position as the result of identity negotiation. Therefore, the results of this study is used as guidance for creating educational model for children in the areas where local religions are discriminated against. The implementation of the learning model is expected to develop awareness about tolerance to religious differences and establish social harmony. Furthermore, future research is needed to implement the intervention of co-cultural strategies in empowering the minority, in particular local religious groups, in dealing with discrimination by using action research methods. Future research can also be directed towards the comprehension of cocultural communication patterns from the dominant religious group's perspectives so that the naturalization of dominant group oppressions can be understood.

\section{REFERENCES}

Asmara, G. (2018). The Principles of Religious Tolerance and Harmony Among The People of Sasak Tribe in Lombok Island, Indonesia. Journal of Legal, Ethical and Regulatory Issues, $21(1)$.

Boogert, J. van den. (2017). The Role of Slametan in The Discourse on Javanese Islam. Indonesia And The Malay World. Indonesia and The Malay World, 45(133), 352-372. https://doi.org/https://doi.or g/10.108o/13639811.2017.1345166

Chornet, D., \& Parr, B. H. (2017). Situations in Intercultural Communication: A SixStep Iterative Training Cycle. Journal of Intercultural Communication, 43. https://immi.se/intercultural/nr43/ chornet.html

Chuah, S. H., Gachter, S., Hoffmann, R., \& Tan, J. H. W. (2016). Religion, Discrimination and Trust Across Three Cultures. European Economic Review, 90, 280-301. https://doi.org/https://doi. org/10.1016/j.euroecorev.2016.03.008

Cibangu, S. K., \& Hepworth, M. (2016). The Uses of Phenomenology and 
Phenomenography: A Critical Review. Library \& Information Science Research, 38(2). $\quad$ https://doi.org/https://doi. org/10.1016/j.lisr.2016.05.001

Erdianto, K. (2017). Penetapan Presiden 1965 soal Penodaan Agama Kerap Ditafsirkan Diskriminatif. Kompas. Com. https://nasional.kompas.com/ $\mathrm{read} / 2017 / 10 / 23 / 15091911 /$ penetapanpresiden-1965-soal-penodaan-agamakerap-ditafsirkan-diskriminatif

Eyber, C., Kachale, B., Shields, T., \& Ager, A. (2018). The role and experience of local faith leaders in promoting child protection: a cases tudy from Malawi. Intervention Journal, 16(1), 31-37. https://doi.org/https://doi. org/10.1097/WTF.ooooooooooooo156

Glenn, C. L., \& Johnson, D. L. (2012). What they see as acceptable:" A cocultural theoretical analysis of Black male students at a Predominantly White Institution. Howard Journal of Communication, 23(4), 351-368. https://doi.org/https://doi.org/10.1080 /10646175.2012.722817

Gudykunst, W. B. (2002). Intercultural Communication Theories. In M. K. Asante, W. B. Gudykunst, \& B. Mody (Eds.), Handbook of International and Intercultural Communication (2nd ed.). SAGE Publication.

Gupta, G., Mahmud, M., Maitra, P., Mitra, S., \& Neelim, A. (2018). Religion, minority status, and trust: Evident from a field experiment. Journal of Economic Behavior \& Organization, 146, 180-205. https://doi.org/https:// doi.org/10.1016/j.jebo.2017.11.028

Hafiz, M., \& Dja'far, A. M. (2016). Ringkasan Kebijakan Kemerdekaan Beragama atau Berkeyakinan di Indonesia dan Perlindungan Negara. Wahid Foundation. http://wahidfoundation. org/source/download/Ringkasan_ Kebijakan_KBB_di_Indonesia_dan_ Perlindungan_Negara.pdf
Harney, M. (2015). Naturalizing Phenomenology - A Philosophical Imperative. Progress in Biophysics and Molecular Biology, 119(3), 661669. https://doi.org/https://doi. org/10.1016/j.pbiomolbio.2015.08.005

Jong, E. de, \& Tiwikromo, A. (2017). Friction within harmony: Everyday dynamics and the negotiation of diversity in Yogyakarta, Indonesia. Journal of Southeast Asian Studies, 48(1), 21-90. https://doi.org/https://doi.org/10.1017/ SoO22463416000485

Jubba, H., Pabbajah, M., Prasodjo, Z. H., \& Qodir, Z. (2019). The Future Relations between the Majority and Minority Religious Groups, Viewed from Indonesian Contemporary Perspective: A Case Study of the Coexistence of Muslims and the Towani Tolotang in Amparita, South Sulawesi. International Journal of Islamic Thought, 16, 13-23. https://doi.org/ https://doi.or/10.24035/ijit.16.2019.002

Komnasham. (2016). Upaya Negara Menjamin Hak-Hak Kelompok Minoritas Di Indonesia Sebuah Laporan Awal.

Kriještorac, M. (2018). Imposing Particular Identities:TheBalkansasaMeetingPlace of Ethnicities and Religions. Insight Turkey, 20(3), 241-264. https://doi.org/ https://doi.org/10.25253/99.2018203.10

Kung, F. Y. H., Chao, M. M., Yao, D. J., Adair, W. L., Fu, J. H., \& Tasa, K. (2018). Bridging Racial Devides: Social Constructionist (vs. Essentialist) Beliefs Facilitate Trust in Intergroup Contexts. Journal of Exerimental Social Psychology, 74, 121-134. https://doi.org/https://doi. org/10.1016/j.jesp.2017.09.008

Levin, H. Y., Jacobs, A., \& Arora, K. (2016). To Accommodate or Not to Accommodate: (When) Should the State Regulate Religion to Protect the Rights of Children and Third Parties? Washington and Lee Review, 73, 915-1016. https://doi.org/ https://doi.org/10.2139/ssrn.2641076 
Littlejohn, S. W., Foss, K. A., \& Oetzel, J. G. (2017). Theories of Human Communication (Eleventh). Waveland Press.

Lubis, A. Y. (2015). Pemikiran Kritis Kontemporer, Dari Teori Kritis, Culture Studies, Feminisme, Postkolonial Hingga Multikulturalisme. RajaGrafindo Persada.

Mellisa, A. (2015). Nasib Penghayat di Indonesia. PUSAD Paramadina. https://www.paramadina-pusad.or.id/ nasib-penghayat-di-indonesia/

Neuman, W. L. (2007). Basic of Social Research : Qualitative and Quantitative Approaches. Pearson Education Inc.

Priyanto, M. A. (2017). Pemakaman Penganut Aliran Kepercayaan Ditolak Oleh TPU. Tribunnews.Com. https://www. tribunnews.com/regional/2017/10/o6/ pemakaman-penganut-alirankepercayaan-ditolak-oleh-tpuakhirnya-dikuburkan-di-sini

Rahardjo, T. (2004). Mindfulness, Komunikasi Antaretnis (Kasus Kampung Balong Sudiroprajan Surakarta. Universitas Indonesia.

Rahardjo, T., \& Lukmantoro, T. (2015). Membangun Model Komunikasi Masyarakat Multi Agama.

Rasna, I. W., \& Tantra, D. K. (2017). Reconstruction of Local Wisdom for Character Education Through the Indonesia Language Learning: An Ethno-Pedagogical Methodology. Theory and Practice in Languange Studies, 7(12), 1229-1235. https:// doi.org/http://dx.doi.org/10.17507/ tpls.0712.09
Razzante, R. J., \& Orbe, M. P. (2018). Two Sides of the Same Coin: Conceptualizing Dominant Group Theory in the Context of Co-Cultural Theory. Communication Theory, 28(3), 354-375. https://doi.org/ https://doi.org/10.1093/ct/qtxoo8

Shaver, J. H., Throughton, G., Sibley, C. G., \& Bulbulia, J. A. (2016). Religion and the Unmaking of Prejudice toward Muslims: Evidence from a Large National Sample. PLoS ONE, 11(3), 1-25. https://doi.org/https://doi.org/10.1371/ journal.pone.0150209

Simmons, N. (2013). Speaking Like a Queen in RuPaul's Drag Race: Towards a Speech Code of American Drag Queens. Sexuality \& Culture, 18(3). https://doi. org/https://doi.org/10.1007/s12119-0139213-2

Sloan, L. M., \& Schmitz, C. L. (2018). Critical Multiculturalism and Intersectionality in a Complex Words (2nd ed.). Oxford University Press.

Spiteri, D. (2017). Multiculturalism, Higher Education and Intercultural Communication Developing StrengthsBased Narratives for Teaching and Learning. Palgrave Macmillan.

Tremblay, A. (2019). Diversity in Decline? The Rise of the Political Right and the Fate of Multiculturalism. Palgrave Macmillan.

Turner-Zwinkels, F. M., Postmes, T., \& Zomeren, M. van. (2015). Achieving Harmony among Different Social Identities within the Self-Concept: The Consequences of Internalising a GroupBased Philosophy of Life. PLoSONE, 10(11), 1-32. https://doi.org/https://doi. org/10.1371/journal.pone.0137879 